\author{
DEPARTMENT OF THE INTERIOR \\ UNITED STATES GEOLOGICAL SURVEY
}

Prepared under the joint sponsorship of the GOVERNMENT OF LIBERIA and the AGENCY FOR INTERNATIONAL DEVELOPMENT U.S. DEPARTMENT OF STATE

\title{
AEROMAGNETIC MAP \\ OF THE ZORZOR QUADRANGLE, LIBERIA \\ By
}

John C. Behrendt and Cletus S. Wotorson

FOLIO OF THE ZORZOR QUADRANGLE, LIBERIA

MAP I-773 B

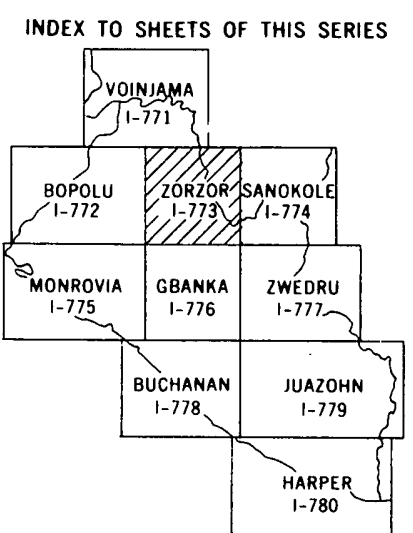

PUBLISHED BY THE U.S. GEOLOGICAL SURVEY RESTON, VA. 22092 1974 